\title{
Effect of sowing dates and varieties for higher productivity of Indian mustard (Brassica juncea L.)
}

\author{
Abhinaw Kumar Singh ${ }^{1}$, Hanumant Singh $^{2}$, O.P. Rai ${ }^{3}$, Ghanshyam Singh $^{3}$, Ved Prakash \\ Singh $^{3}$, Naveen Prakash Singh ${ }^{3}$ and Rajneesh Singh ${ }^{3}$ \\ ${ }^{1}$ Department of Agronomy, CCS Haryana Agricultural University, Hisar-125004 (Haryana), INDIA \\ ${ }^{2}$ Department of Soil Science, CCS Haryana Agricultural University, Hisar-125004 (Haryana), INDIA \\ ${ }^{3}$ Department of Agronomy, Narendra Deva University of Agriculture and Technology, Kumarganj, Faizabad - \\ 224229 (U.P.), INDIA \\ *Corresponding author. E-mail: dr.singhak99@gmail.com
}

Received: May 8, 2016; Revised received: February 16, 2017; Accepted: April 28, 2017

\begin{abstract}
A field experiment was conducted at Agronomy Research Farm, N.D. University of Agriculture and Technology, Kumarganj, Faizabad during the Rabi season of 2011-12 to access the effect of sowing dates and varieties for higher productivity of Indian mustard (Brassica juncea L.). Treatments consisted of four dates of sowing viz. $D_{1}$ (25 $5^{\text {th }}$ September $), D_{2}\left(5^{\text {th }}\right.$ October $), D_{3}\left(15^{\text {th }}\right.$ October $)$ and $D_{4}\left(25^{\text {th }}\right.$ October $)$ was kept as main plot and five varieties viz. $V_{1}$ (Rohini), $V_{2}$ (Maya), $V_{3}$ (Coral-437), $V_{4}$ (Kranti) and $V_{5}$ (PBR-357) was kept as sub plot replicated three under split plot design. Results revealed that all the growth, yield attributes and quality were increased significantly under $25^{\text {th }}$ October sowing. The agronomical parameters like initial plant stand per running meter, plant height $(\mathrm{cm})$, days taken to $50 \%$ flowering, leaf area index, dry matter accumulation $\left(\mathrm{g} \mathrm{plant}^{-1}\right)$ and yield and yield attributes like number of siliquae plant ${ }^{-1}$, number of seed siliqua $a^{-1}$, length of siliqua $(\mathrm{cm})$ and seed, stover yields $\left(\mathrm{q} \mathrm{ha} \mathrm{h}^{-1}\right)$ of mustard crop were significantly higher with variety Coral-437. The highest seed yield oil content $\%$ was computed under $25^{\text {th }}$ October sowing with Coral-437 variety. $25^{\text {th }}$ October sowing with Coral-437 variety proved the most remunerative and economically feasible for cultivation of Indian mustard under the agro climatic conditions of eastern U.P.
\end{abstract}

Keywords: Different Varieties, Indian mustard, Productivity, Sowing dates

\section{INTRODUCTION}

India is one among the leading oil seed producing countries in the world. Oilseeds form the second largest agricultural commodity after cereals. In India mustard is the second important edible oil seed crop after groundnut. It plays an important role in the oil seed economy of the country. In India, during 2011-2012, the rapeseed and mustard crop had production of about 6.78 million tonnes from an area of 5.92 mha with an average productivity of $1145 \mathrm{~kg} \mathrm{ha}^{-1}$. However, in Uttar Pradesh it is grown in 0.64 mha with production of 0.72 million tonnes. The average productivity of Uttar Pradesh is $1125 \mathrm{~kg} \mathrm{ha}^{-1}$. (Anonymous, 2012). In India, its cultivation is mainly confined in the states viz., Rajasthan, Uttar Pradesh, Madhya Pradesh, Haryana, Punjab, Assam, Bihar, Gujarat and West Bengal. Among the states, Uttar Pradesh alone produces about 20 per cent of total mustard production in India. Indian mustard belongs to cruciferae family, genus Brassica and species juncea. Rapeseed is locally called sarson, toria, yellow toria, whereas, Mustard is called rai or laha. Though, the rapeseed and mustard belong to the same family and genus, they differ with respect to their plant characteristics.

Mustard is cultivated in mostly under temperate climates. It is also grown in certain tropical and subtropical regions as a cold weather crop. Indian mustard is reported to tolerate annual precipitation of 500 to $1200 \mathrm{~mm}$, annual temperature of 6 to $27{ }^{\circ} \mathrm{C}$, and soil $\mathrm{pH}$ of 4.3 to 8.3. Rapeseed - mustard follows $\mathrm{C}_{-3}$ pathway for carbon assimilation. Therefore, it has efficient photosynthetic response at 15 to $20{ }^{0} \mathrm{C}$ temperature. At this temperature the plant achieve maximum $\mathrm{CO}_{2}$ exchange range which declines thereafter. Mustard requires well drained sandy loam soil. Rapeseed - mustard has a low water requirement (240 - $400 \mathrm{~mm})$ which fits well in the rain fed cropping system. Nearly $20 \%$ these crops are rainfed (Shekhawat et al., 2012). Rapeseed and mustard are usually sown by the end of September to second fortnight of October in north India when grown as a sole crop or on dates of the main crop when sown as mixed or intercrop. But, with the development of new varieties of crops and adoption of multiple cropping systems under irrigated condition, it has become essential to extend their sowing from October to mid of November or even later. Singh and Singh (2002) conducted a field experiment at Faizabad 
(Uttar Pradesh) and recorded higher stover yield with $14^{\text {th }}$ October sowing as compared to $29^{\text {th }}$ October, $13^{\text {th }}$ November and $28^{\text {th }}$ November sowing.

Delayed sowing owing to change in biotic and abiotic environmental conditions may have adverse effect the crop performance. It necessitates developing suitable agro techniques to augment the productivity of the crop. Among the different agronomic practices, optimum sowing time plays an important role to fully exploit the genetic potentiality of a variety as it provides optimum crop growing environment such as temperature, humidity and light etc. Sowing time is one of the most important non-monetary input which influences to a great extent on both the productivity of seed and oil (Shekhawat et al., 2012). Awasthi et al., 2007 at Kanpur, Uttar Pradesh, to evaluate the effect of sowing dates (15 and 30 October) on growth and yield of two varieties of ('Vaibhav' and 'Urwashi') of Indian mustard under rainfed conditions. Sowing on 15 October achieved higher seed compared to sowing on 30 October.

Keeping in view the importance of mustard as a major oil seed crop of this state the present study was investigated to examine the suitable sowing dates and varieties are the highly remunerative of the cultivation of Indian mustard.

\section{MATERIALS AND METHODS}

A field experiment was conducted during the rabi season 2011-2012 at Agronomy Research Farm, Narendra Deva University of Agriculture and Technology, Kumarganj, Faizabad (U.P.). Geographically, this region falls under sub-tropical climate and it is situated at $26^{\circ} .47^{\prime} \mathrm{N}$ latitude $82^{\circ} .12^{\prime} \mathrm{E}$ longitude and an indogangetic alluvial of eastern Uttar Pradesh in India. The soil samples were collected at random from the experimental field with the help of soil auger up to a depth of $15 \mathrm{~cm}$ prior to application of fertilizers. The soil samples were mixed properly and a composite sample was obtained for analysis. The soil was silt loam in texture, with Soil pH, E.C organic carbon value of $8.2,0.23 \mathrm{dsm}^{-1}$ and $0.37 \%$ respectively. It was low in available nitrogen $\left(194.25 \mathrm{~kg} / \mathrm{ha}^{-1}\right)$, while the availability of phosphorus (18.03 $\mathrm{kg} / \mathrm{ha})$, potassium $(250.25 \mathrm{~kg} / \mathrm{ha})$ and sulphur $\left(10.50 \mathrm{~kg} / \mathrm{ha}^{-1}\right)$ is medium. The treatments consisted of with four sowing dates as main plots viz. 25 September, 05 October, 15 October, and 25 October 2011 and five varieties viz., Rohini, Kranti, Coral-437, Maya and PBR-357 as sub plots, designed in split plot with three replications. The all varieties belong to (Brassica juncea) Indian mustard. The crop was fertilized with a uniform dose of nitrogen, phosphorus and potassium@120,60, and $40 \mathrm{~kg}$ $\mathrm{ha}^{-1}$ respectively. Sulphur was applied as per treatment through elemental sulphur. Two irrigation were given to the mustard crop first irrigation was gives at 30 days after sowing and second, irrigation at flowering stage of the crop. Five plants were randomly selected and tagged in each plot, dates of phenological event (Patel and Mehta 1987) viz: growth and growth parameter yield and yield attributes, and others parameters such as quality attributes were recorded from each treatment. Seed yield from each treatments were recorded at harvest and expressed in $\mathrm{kg}$ per ha. Daily weather data such as rainfall, maximum and minimum temperatures, relative humidity, evaporation wind speed and sunshine during crop period were collected through agrometerological observatory of the university. Since mustard is indeterminate crop, its flowering and siliqua formation phases take a long time. According to various phenological events from emergence to maturity, whole life cycle of the crop was divided into vegeta-

Table 1. Initial plant stands per running meter and plant height and days taken to $50 \%$ flowering and leaf area index as

\begin{tabular}{|c|c|c|c|c|c|c|c|c|c|}
\hline \multirow[t]{2}{*}{ Treatment } & \multirow{2}{*}{$\begin{array}{l}\text { Initial plant } \\
\text { stand per } \\
\text { running } \\
\text { meter }\end{array}$} & \multicolumn{4}{|c|}{ Plant height (cm) } & \multirow{2}{*}{$\begin{array}{l}\text { Days taken } \\
\text { to }(50 \%) \\
\text { flowering }\end{array}$} & \multicolumn{3}{|c|}{ Leaf area index } \\
\hline & & $\begin{array}{c}\text { 30 } \\
\text { DAS }\end{array}$ & 60 DAS & 90 DAS & $\begin{array}{c}\text { at } \\
\text { harvest }\end{array}$ & & 30 DAS & $\begin{array}{c}\text { 60 } \\
\text { DAS }\end{array}$ & $\begin{array}{c}90 \\
\text { DAS }\end{array}$ \\
\hline \multicolumn{10}{|l|}{ Date of sowing } \\
\hline $\mathrm{D}_{1}$ (25 Sep.) & 6.09 & 13.07 & 47.23 & 106.52 & 110.99 & 47.46 & 2.10 & 4.34 & 3.63 \\
\hline $\mathrm{D}_{2}$ (05 Oct.) & 6.13 & 15.43 & 51.94 & 117.15 & 122.05 & 48.57 & 2.48 & 4.78 & 4.00 \\
\hline $\mathrm{D}_{3}$ (15 Oct.) & 6.34 & 15.86 & 58.09 & 131.02 & 136.50 & 51.64 & 2.55 & 5.34 & 4.47 \\
\hline $\mathrm{D}_{4}$ (25 Oct.) & 6.41 & 16.04 & 62.28 & 140.46 & 146.34 & 53.19 & 2.57 & 5.73 & 4.79 \\
\hline SEm \pm & 0.19 & 0.46 & 1.47 & 2.18 & 3.63 & 1.52 & 0.07 & 0.14 & 0.07 \\
\hline $\mathrm{CD}(\mathrm{P}=0.05)$ & 0.67 & 1.59 & 5.10 & 7.53 & 12.55 & 5.27 & 0.25 & 0.47 & 0.26 \\
\hline \multicolumn{10}{|l|}{ Varieties } \\
\hline $\mathrm{V}_{1}$ (Rohini) & 6.07 & 14.86 & 50.54 & 113.97 & 118.75 & 47.25 & 2.38 & 4.65 & 3.89 \\
\hline $\mathrm{V}_{2}($ Kranti) & 6.13 & 15.02 & 54.46 & 122.83 & 127.97 & 48.78 & 2.41 & 5.01 & 4.19 \\
\hline $\mathrm{V}_{3}($ Coral-437) & 6.21 & 15.33 & 59.37 & 133.89 & 139.50 & 54.42 & 2.46 & 5.46 & 4.57 \\
\hline $\mathrm{V}_{4}$ (Maya) & 6.08 & 14.98 & 51.52 & 116.19 & 121.05 & 47.07 & 2.40 & 4.74 & 3.96 \\
\hline $\mathrm{V}_{5}(\mathrm{PBR}-357)$ & 6.20 & 15.30 & 58.55 & 132.05 & 137.58 & 53.57 & 2.46 & 5.38 & 4.50 \\
\hline SEm \pm & 0.16 & 0.41 & 1.76 & 4.32 & 4.20 & 1.33 & 0.07 & 0.16 & 0.15 \\
\hline $\mathrm{CD}(\mathrm{P}=0.05)$ & 0.47 & 1.19 & 5.08 & 12.45 & 12.11 & 3.84 & 0.19 & 0.47 & 0.42 \\
\hline D X V & NS & NS & NS & NS & NS & NS & NS & NS & NS \\
\hline
\end{tabular}


Abhinaw Kumar Singh et al. / J. Appl. \& Nat. Sci. 9 (2): 883 - 887 (2017)

Table 2. Number of branches plant ${ }^{-1}$ and dry matter accumulation $\left(\mathrm{g}\right.$ plant $\left.{ }^{1}\right)$ as influenced by different date of sowing and varieties.

\begin{tabular}{|c|c|c|c|c|c|c|c|c|}
\hline \multirow{2}{*}{ Treatment } & \multicolumn{4}{|c|}{ No. of branches (plant ${ }^{-1}$ ) } & \multicolumn{4}{|c|}{ Dry matter accumulation (g plant ${ }^{1}$ ) } \\
\hline & 30 DAS & 60 DAS & 90 DAS & at harvest & 30 DAS & 60 DAS & 90 DAS & at harvest \\
\hline \multicolumn{9}{|l|}{ Date of sowing } \\
\hline $\mathrm{D}_{1}$ (25 Sep.) & 1.42 & 8.92 & 24.89 & 23.51 & 1.50 & 15.54 & 59.81 & 102.21 \\
\hline $\mathrm{D}_{2}$ (05 Oct.) & 1.67 & 9.81 & 27.38 & 25.85 & 1.77 & 17.09 & 65.77 & 112.40 \\
\hline $\mathrm{D}_{3}(15$ Oct.) & 1.72 & 10.98 & 30.62 & 28.91 & 1.82 & 19.11 & 73.56 & 125.71 \\
\hline $\mathrm{D}_{4}(25$ Oct. $)$ & 1.74 & 11.77 & 32.82 & 31.00 & 1.84 & 20.40 & 78.86 & 134.77 \\
\hline $\mathrm{SEm} \pm$ & 0.05 & 0.28 & 0.51 & 0.77 & 0.05 & 0.49 & 1.22 & 3.34 \\
\hline $\mathrm{CD}(\mathrm{P}=0.05)$ & 0.17 & 0.96 & 1.76 & 2.66 & 0.18 & 1.68 & 4.23 & 11.55 \\
\hline \multicolumn{9}{|l|}{ Varieties } \\
\hline $\mathrm{V}_{1}$ (Rohini) & 1.61 & 9.55 & 26.64 & 25.15 & 1.70 & 16.62 & 63.99 & 109.36 \\
\hline $\mathrm{V}_{2}$ (Kranti) & 1.63 & 10.29 & 28.70 & 27.11 & 1.72 & 17.92 & 68.96 & 117.85 \\
\hline $\mathrm{V}_{3}($ Coral-437) & 1.66 & 11.22 & 31.29 & 29.55 & 1.75 & 19.53 & 75.81 & 128.47 \\
\hline $\mathrm{V}_{4}$ (Maya) & 1.62 & 9.73 & 27.15 & 25.64 & 1.71 & 16.95 & 65.24 & 111.48 \\
\hline $\mathrm{V}_{5}(\mathrm{PBR}-357)$ & 1.66 & 11.06 & 30.86 & 29.14 & 1.75 & 19.26 & 74.14 & 126.70 \\
\hline $\mathrm{SEm} \pm$ & 0.04 & 0.33 & 1.01 & 0.89 & 0.05 & 0.58 & 2.42 & 3.87 \\
\hline $\mathrm{CD}(\mathrm{P}=0.05)$ & 0.13 & 0.96 & 2.91 & 2.97 & 0.14 & 1.67 & 6.99 & 11.16 \\
\hline D X V & NS & NS & NS & NS & NS & NS & NS & NS \\
\hline
\end{tabular}

tive, flowering and siliqua formation phase, and entire growth period corresponding phases were summed up. All the data were tabulated and analysed statistically as per the procedure suggested by Panse and Sukhatme (1978). The ' $F$ ' (Fisher's) test was used for judging the significance of the treatment mean at 5 per cent probability level. Whenever ' $F$ ' test showed significant difference, the differences between treatments means were further tested using critical difference (CD) values.

\section{RESULTS AND DISCUSSION}

The result and discussion of the preceding are hereby discussed briefly. An attempt has been made to interpret and explain the results with a view to understand the 'causes' and 'effect' relationship among growth, yield attributes, and yield quality of the mustard crop observed according to dates of sowing and varieties.

Effect of dates of sowing

Agronomical parameters: Thermo and photosensitivity of oil seed crop limits the sowing period. Very early sowing causes the mortality of tender seedling due to high temperature. However delayed sowing also reduce the production due to poor performance of the crop as the result of reduced growing period, has tens maturity and ultimately causes the reduction in yield. Besides, westerly hot winds accelerate the maturity and thereby reduce the yield. Therefore, to harvest a good crop, sowing at appropriate time which provides congenial environment is utmost important. Initial plant population of the crop was maintained properly by thinning. Since soil moisture in the seedling zone was not a limiting factor for germination of the seeds of the crop pre sowing irrigation was applied in all the four dates of sowing.

The dates of sowing brought significant variation on different agronomical parameters recorded at successive stages of Indian mustard, viz. initial plant stand per running meter, Plant height, days taken to $50 \%$ flowering, leaf area index, dry matter accumulation plant $^{-1}$ and number of branches plant ${ }^{-1}$. Initial plant stands per running meter of mustard was not influ-

Table 3. Yield attributes Seed yield, stover yield, and harvest index as influenced by different date of sowing and varieties.

\begin{tabular}{|c|c|c|c|c|c|c|c|}
\hline \multirow{2}{*}{ Treatments } & No. of siliquae & Length of & No. of seeds & 1000-ssed & Seed yield & Stover yield & Harvest index \\
\hline & plant $^{-1}$ & siliqua $(\mathrm{cm})$ & Siliqua $^{-1}$ & weight (g) & $\left(\mathrm{q} \mathrm{ha} \mathbf{h}^{-1}\right)$ & $\left.(\mathbf{q ~ h a})^{-1}\right)$ & \\
\hline \multicolumn{8}{|l|}{ Date of sowing } \\
\hline $\mathrm{D}_{1}$ (25 Sep.) & 239.82 & 5.68 & 10.91 & 4.39 & 14.02 & 43.84 & 24.36 \\
\hline $\mathrm{D}_{2}$ (05 Oct.) & 263.74 & 6.24 & 11.21 & 4.44 & 15.42 & 48.21 & 24.31 \\
\hline $\mathrm{D}_{3}$ (15 Oct.) & 294.96 & 6.98 & 12.54 & 4.68 & 17.24 & 53.92 & 24.31 \\
\hline $\mathrm{D}_{4}$ (25 Oct.) & 316.22 & 7.49 & 13.44 & 4.74 & 18.49 & 57.81 & 24.31 \\
\hline SEm \pm & 7.75 & 0.17 & 0.34 & 0.14 & 0.41 & 1.69 & 1.04 \\
\hline $\mathrm{CD}(\mathrm{P}=0.05)$ & 26.81 & 0.59 & 1.17 & 0.48 & 1.42 & 5.86 & 3.58 \\
\hline \multicolumn{8}{|l|}{ Varieties } \\
\hline $\mathrm{V}_{1}$ (Rohini) & 256.59 & 6.07 & 10.91 & 4.56 & 15.00 & 46.91 & 24.21 \\
\hline $\mathrm{V}_{2}($ Kranti $)$ & 276.52 & 6.55 & 11.75 & 4.61 & 16.17 & 50.55 & 24.47 \\
\hline $\mathrm{V}_{3}($ Coral-437) & 301.44 & 7.14 & 12.81 & 4.50 & 17.62 & 55.10 & 24.40 \\
\hline $\mathrm{V}_{4}$ (Maya) & 261.58 & 6.19 & 11.12 & 4.47 & 15.29 & 47.82 & 24.22 \\
\hline $\mathrm{V}_{5}(\mathrm{PBR}-357)$ & 297.28 & 7.04 & 12.64 & 4.66 & 17.38 & 54.34 & 24.31 \\
\hline SEm \pm & 8.30 & 0.21 & 0.34 & 0.12 & 0.56 & 1.50 & 0.94 \\
\hline $\mathrm{CD}(\mathrm{P}=0.05)$ & 23.93 & 0.61 & 0.97 & 0.35 & 1.63 & 4.34 & 2.72 \\
\hline D X V & NS & NS & NS & $\mathrm{NS}$ & $\mathrm{NS}$ & $\mathrm{NS}$ & $\mathrm{NS}$ \\
\hline
\end{tabular}


enced significantly due to dates of sowing. Crop sown on $25^{\text {th }}$ October produced significantly taller plant over $25^{\text {th }}$ September sowing. Dates of sowing had no significant influence of days taken to $50 \%$ flowering of mustard. Due to higher leaf area index at all the stages (Table 1) and higher number of branches plant ${ }^{1}$ recorded at harvest as shown in (Table 2). This could be ascribed due to prolonged vegetative growth period because of congenial environmental conditions, especially atmospheric temperature which formed a basis for rapid cell division in the meristemmatic tissues of the experimental crop which led to better growth attributes under normal sowing $\left(25^{\text {th }}\right.$ October $)$. The early sown crop experienced sub-optimal temperature regime, especially second fortnight of September which retarded their growth as compared to those sown either normal date $25^{\text {th }}$ October or mid- $15^{\text {th }}$ October. Shorter plant and lower LAI under delayed sowing of mustard crop in India have also been reported by Singh and Singh (2002), Kumar et al. (2002), Kurmi (2002) and Panda et al. (2004).

Significant variation was also recorded in dry matter accumulation plant ${ }^{-1}$ due to different dates of sowing (Table 2). Crop sown on $25^{\text {th }}$ October accumulated significantly higher dry mater plant ${ }^{-1}$ which did not differed significantly than those sown on $15^{\text {th }}$ October. However, crop sown on $5^{\text {th }}$ October and $25^{\text {th }}$ September accumulated lower dry matter than $25^{\text {th }}$ October sowing. Accumulation of dry matter in the plant is directly related to their vigorous plant height, leaf area index and number of branches plant ${ }^{-1}$ which were appreciably depressed as sowing were delayed. Drastic decrease in dry matter accumulation of mustard was also observed by Panda et al. (2004) and Khushu and Singh (2005).

Yield attributes: Yield attributes like number of siliqua plant ${ }^{-1}$, length of siliqua, number of seeds siliqua ${ }^{-1}$ and 1000 seed weight were successively decreased with early sowing of the crop (Table 3 ). However the difference between $25^{\text {th }}$ October and $15^{\text {th }}$ October sowing were non-significant. Early and late sowing restricted the crop growth duration and also induced early flowering. It is also reduced pod initiation and seed setting to a great extant as compared to $25^{\text {th }}$ October. This might be due to the fact that low temperature during the month of September not only restricted the crop growth but also induced lower rate of pollination and flower abortion, shedding in early sown mustard crop. Similar results were also observed by Thakur and Singh 1998, Singh et al., 2001, Singh and Singh 2002, and Panda et al., 2004).

Yield: Seed and Stover yield of mustard were significantly affected due to different dates of sowing (Table 3). Crop sown on $25^{\text {th }}$ October recorded significantly higher seed yield as compared to $5^{\text {th }}$ October and $25^{\text {th }}$ September sowing mainly due to better translocation of photosynthates from source to sink. A similar trend was also recorded in stover yield of mustard; this might be due to poor growth and better translocation of photosynthates from source to sink. All the growth and yield attributes which determined the seed and stover yield of mustard crop, were adversely influenced when the sowing were done on early dates. Significant reduction in seed and stover yield of mustard in early have also been reported by several other workers (Panwar et al., 2000, Khichar et al., 2000, Singh et al., 2001, Sihag et al., 2003, Panda et al., 2004 and Khushu and Singh, 2005.

\section{Effect of varieties}

Agronomical parameter: The maximum plant height (cm) was recorded for Coral-437 which was significantly superior to Maya and Rohini at all the stages of the crop. Increase in the plant height $(\mathrm{cm})$ was observed at all growth stages of mustard crop except, 30 DAS.

The maximum leaf area index and Number of branches plant ${ }^{-1}$ were recorded with Coral-437 which was significantly superior to Maya and Rohini at all the stages of the crop, except 30DAS. Dry matter accumulation plant $^{-1}$ was also higher in Coral-437 which was significantly superior to Maya and Rohini at all the stages of the crop, except 30 DAS. Days taken to $50 \%$ flowering were also higher in Coral-437 which was significantly superior to Kranti, Rohini and Maya. (Table 1 and 2). The probable reason may be attributed to genetic characters of Coral-437 which has higher capacity to utilized the photosynthates more efficiently through maximum leaf area index, number of branches plant $^{-1}$ and ultimately the dry matter production, the similar findings have been reported by Bharadwaj 1991, Kumar et al., 2000, Shukla et al., 2001 and Chaplot et al., 2012.

Yield attributes: The maximum number of siliqua plant $^{-1}$ was recorded with variety Coral-437which was significantly higher to Kranti, Maya and Rohini. This was due to higher number of branches plant ${ }^{-1}$. The maximum length of siliqua was recorded with Coral437 which was significantly superior to Kranti, Maya and Rohini. The maximum number of seeds siliqua ${ }^{-1}$ was recorded with Coral-437 which was significantly higher to Kranti, Maya and Rohini. (Table 3). It was attributed due to genetic characters which truly indicated of total photosynthates production, have been reported by several other workers: Kumar et al., 2000, Shukla et al., 2001 and Chaplot et al., 2012.

Yield: The seed yield of mustard mainly depends on the number of siliqua plant ${ }^{-1}$, length of siliqua, number of seed siliqua ${ }^{-1}$ and test weight as these character have high degree of positive correlation with seed yield. The variety with Coral-437 produced higher value of seed and stover yield, which was significantly higher to Kranti, Maya and Rohini (Table 3). (Bharadwaj 1991) reported that Varuna showed significantly higher seed yield and siliquae plant $^{-1}$ than Kranti. The similar 
results were reported by Kumar et al., 2000 and Shukla et al., 2001.

\section{Conclusion}

The highest seed yield and oil content \% was computed under $25^{\text {th }}$ October sowing, with Coral-437 variety. $25^{\text {th }}$ October sowing with Coral-437 variety proved that most remunerative and economically feasible for cultivation of Indian mustard under the agro climatic conditions of eastern U.P.

\section{REFERENCES}

Anonymous (2012). Director's report presented at the $19^{\text {th }}$ annual group meeting of rapeseed-mustard research workers held at ICAR, New Delhi, and 10 Jan. 2012.

Awasthi, U. D., Singh, R. B. and Dubey, S. D. (2007). Effect of sowing date and moisture conservation practice on growth and yield of Indian mustard (Brassica juncea) varieties. Indian Journal of Agronomy, 52 (3): 151-153

Bharadwaj, G. S. (1991). Response of mustard (B. juncea) varieties to nitrogen in north Madhya Pradesh. Indian Journal of Agronomy, 26 (3): 382-384

Chaplot, P. C. Vandeep Amita and Kumar Rakesh (2012). Effect of balanced fertilization and Agrochemcials on growth, yield attributes and yield of mustard varieties. $3^{\text {rd }}$ International Agronomy Congress Nov., 26-30, New Delhi, 1110-1111

Khichar, M. L., Yadav, Y. C., Bishnoi O. P. and Ramniwas (2000). Radiation use efficiency of mustard as influenced by sowing dates, plant spacing and cultivars. Journal of Agrometeorology, 2 (1): 97-99

Khushu, M. K. and Singh M. (2005). Thermal response of mustard under rainfed condition of Jammu. Environment and Ecology, 23 (3): 683-686

Kumar, R., Singh, D. and Singh, H. (2000). Growth and yield of Brassica species as influenced by sulphur application and sowing dates. Indian Journal of Agronomy, 47 (3):417-421

Kurmi, K. (2002). Influence of sowing date on the performance of rapeseed and mustard varieties under rainfed situation of Southern Assam. Journal of Oilseeds Research, 19 (2): 197-198

Panda, B. B., Bandyopadhyay, S. K. and Shivayy, Y. S.
(2004). Effect of irrigation level, sowing dates and varieties on yield attributes, yield, consumptive water use and water use efficiency of Indian mustard (Brassica juncea L.). Indian Journal of Agricultural Sciences, 9 (4): 419-425

Panda, B. B., Shivayy, Y. S. and Bandyopadhyay, S. K. (2004). Growth and development of Indian mustard (Brassica juncea L.) under different varieties of irrigation and date of sowing. Indian Journal of Plant Physiology, 9 (4): 419-425

Panse, V.G. and Sukhatme P.V. (1978). Statistical Methods for Agricultural Workers. Second Edition. - Indian Council of Agricultural Research New Delhi, India.

Panwar, K. S., Sharma, S. K. and Nanwal R. K. (2000). Influence of sowing time on the yield of different mustard cultivars (Brassica spp.) under conserved soil moisture condition. Indian Journal of Agricultural Sciences, 70 (6): 398-399

Patel, I. G. and Mehta A. N. (1987). Assessment of growth and yield of mustard (Brassica juncea (L) Czern and Coss) in relation to heat units. International Journal of Ecology and Environmental Science, 13: 145-55

Shekhawat, Kapila, Rathore, S. S., Premi, O. P. Kandpal, B.K. and Chauhan J.S. (2012). Advances in Agronomic Management of Indian Mustard (Brassica juncea (L.) Czernj. Cosson): An Overview. International Journal of Agronomy, doi:10.1155/2012/408284

Shukla, D.K. Singh, R.P. and Shukla, A. (2001). Response of yellow sarson varieties to different nitrogen levels in Tarai region of U.P. Annals of Agricultural Research, 22 (4): 586-588

Sihag, J. S. Manohar S.S. and Chaudhary T. (2003). Combined effect of sulphur and time of sowing on yield attributes, yield and quality of mustard (Brassica juncea L.). Journal of Eco physiology, 6 (1/2): 65-68

Singh, R., Patidar, M. and Singh, B. (2001). Response of Indian mustard cultivars to different sowing time Indian Journal of Agronomy, 46 (2): 292-295

Singh, S. K. and Singh, G. (2002). Response of Indian mustard (Brassica juncea) varieties nitrogen under varying sowing dates in eastern Uttar Pradesh. Indian Journal of Agronomy, 47 (2):242-248

Thakur, K. S. and Singh, C. M. (1998). Performance of Brassica species dates of sowing in mid hills of Himachal Pradesh. Indian Journal of Agronomy,43(3):464 $-468$ 